\title{
Development and validation of diagrammatic scales to evaluate damage by the two-spotted spider mite (Tetranychus urticae) in peanut
}

\section{Desarrollo y validación de escalas diagramáticas para evaluar el daño por arañuela roja (Tetranychus urticae) en maní}

Ana Cecilia Crenna ${ }^{1}$, Claudio Marcelo Oddino ${ }^{2}$, Santiago Ferrari ${ }^{1}$, Jorge Antonio Giuggia ${ }^{3}$, Diego Giovanini ${ }^{1}$, Francisco Damián Giordano ${ }^{4}$

Originales: Recepción: 01/08/2019 - Aceptación: 18/02/2020

\begin{abstract}
Argentina is the second largest peanut (Arachis hypogaea L.) exporter in the world. The main peanut pest in our country is the two-spotted spider mite (Tetranychus urticae Koch 1836). To date, there is no validated method to quantify this pest. The aim of this work was to develop and validate a logarithmic diagrammatic scale to assess damage by the two-spotted spider mite in peanut. In 2015-16, 200 leaflets were collected from a plot infested with the pest. Damaged leaf area (DLA) was calculated using SisCob software. Six-, seven-, eight- and nine-class scales were proposed. Mean values for each class and scale were obtained with 2-LOG. Leaflets were analyzed by 13 raters who used the four proposed scales. Precision and accuracy were determined by simple linear regression between the DLA and estimated damaged leaf area. Reproducibility was determined by linear regression between estimates of raters combined in pairs. The seven-class scale was the best validated one for all the parameters. Most raters showed constant deviations and overestimated DLA, whereas only one rater presented systematic deviations. This seven-class scale is the first developed and validated one to evaluate two-spotted spider mite damage to peanut in Argentina.
\end{abstract}

\section{Keywords}

diagrammatic scale $\bullet$ Tetranychus urticae $\bullet$ peanut

1 Universidad Nacional de Río Cuarto. Facultad de agronomía y veterinaria. Zoología agrícola. Ruta 36 km 601. Río Cuarto. Córdoba. Argentina. X5804BYA.

ccrenna@ayv.unrc.edu.ar

2 Universidad Nacional de Río Cuarto. Facultad de agronomía y veterinaria.Terapéutica vegetal. IMICO.

3 Universidad Nacional de Río Cuarto. Facultad de agronomía y veterinaria. Terapéutica vegetal. IDAS.

4 IMICO, UNRC-CONICET. 


\section{RESUMEN}

Argentina es el segundo exportador mundial de maní (Arachis hypogaea L.). La principal plaga del cultivo en nuestro país es la arañuela roja (Tetranychus urticae Koch 1836) no existiendo un método validado para su cuantificación, planteándose como objetivo desarrollar y validar una escala logarítmica diagramática de daño para T. urticae en maní. En 2015/16, en un lote con presencia de la plaga, se colectaron 200 folíolos, a los que se les calculó el área foliar dañada (AFD) a través del software SisCob. Se plantearon escalas de seis, siete, ocho y nueve clases obteniendo el valor medio de cada clase con el programa 2-LOG. Los folíolos fueron analizados por 13 evaluadores con el uso de las cuatro escalas. La validación por precisión y exactitud se realizó por regresión lineal entre el AFD y la estimada, y la reproducibilidad por regresión lineal entre las estimaciones de los evaluadores combinados de a pares. La escala de siete clases fue la mejor validada por todos los parámetros. La mayoría de los evaluadores presentaron desvíos constantes; mientras que solo un evaluador presentó desvíos sistemáticos. Esta escala de siete clases es la primera desarrollada y validada para evaluar el daño por arañuela roja en maní en Argentina.

\section{Palabras clave}

escala diagramática $\bullet$ Tetranychus urticae • maní

\section{INTRODUCTION}

World production of peanut (Arachis hypogaea L.) is expanding, with more than 40 million $t$ of in-shell peanut and 6 million tons of oil having been produced in the last decade. Argentina is one of the main peanut exporter countries worldwide; more than $90 \%$ of the area of Córdoba province is cultivated with peanut, and almost all the processing industry is concentrated in that province (1).

In Argentina, peanut crop is affected by a low number of arthropod pests; however, under certain climatic conditions, especially in years of low precipitations, the two-spotted spider mite Tetranychus urticae Koch 1836 becomes an important concern in several peanut plots (6). Under prolonged dry and hot weather, this pest exhibits fast development and overlapping generations, reaching important infestation levels over a short period (23).

The two-spotted spider mite causes damage directly and indirectly to peanut: by ingesting leaf cell contents with needle-like mouthparts, producing white or yellow specks called stipples, and through the weaving of webs, which contribute to the reduction of the crop photosynthetic process, respectively $(6,35)$.

In decision-making in pest control, it is necessary to generate an economic injury level (EIL). Although some EIL has been calculated based on the number of individuals per leaf or leaflet (32), it is important to have an objective tool for the quantification of the damage caused by it. One of the best ways to evaluate injury by a pest or disease affecting the leaf area is using a scale that represents the damage that has being caused by that pest or disease $(29,33)$.

Diagrammatic scales are useful for monitoring pests and diseases, supporting decision making about chemical control, assessing cultivar behavior, developing disease progress curves, and evaluating management practices $(3,4,8,38)$.

In Argentina, scales have been developed to quantify foliar diseases in peanut $(19,31)$, but only one scale quantifies damage caused by insect pests in this crop (10). Scales that evaluate the spider mite in other crops have been reported $(13,36)$, but none evaluates damage caused by two-spotted spider mite to peanut, the main pest damaging this crop in Argentina. For this reason, the aim of this work was to develop and validate a logarithmic diagrammatic scale of damage by the two-spotted spider mite in peanut. 


\section{MATERIALS AND METHODS}

The study was conducted in a plot heavily infested with the two-spotted spider mite, located in Río Cuarto department, south of Córdoba province, Argentina, (33 02' 32.33" S, $63^{\circ} 30^{\prime} 14,02^{\prime \prime} \mathrm{W}$ ), during the 2015-2016 crop season. Two hundred leaflets were collected with the aim of having a representative sample of the different degrees of damage. Each leaflet was photographed; photographs were processed using the software SisCob v1.0 (18), which measures the healthy leaf area (HLA) and the damaged leaf area (DLA). Percentage of damage of each leaflet was calculated based on those measurements. In addition, images with a schematic representation of each leaflet were generated.

Scales of different numbers of damage classes (six, seven, eight and nine) were proposed, considering that these numbers of classes were suitable for estimating disease damage and consequent losses $(2,15,37,38,39)$. Considering the maximum real value of DLA obtained by the software and the number of classes selected to develop the scales, the intervals of each class were defined using the program 2-LOG v1.0 for Windows ${ }^{\circledR}(30)$. This program calculates the values for the upper limit (UL), lower limit (LL) and the midpoint (MP) of each class of the proposed scales.

Diagrammatic scales were performed using the images generated with the software SisCob v1.0, selecting the leaflet that represented the average DLA value for each of the classes. Image digitalization allows a rapid sample processing and enhances the capacity to discriminate between healthy and damaged area $(4,37)$.

Scales were validated using the field-collected leaflets, which were analyzed by 13 raters. Each leaflet was evaluated using the four scales and was assigned to a class, then the midpoint value corresponding to that class was assigned to each leaflet. Besides being of easy and rapid application, a scale needs to be validated in terms of precision, accuracy and reproducibility $(8,20,25,38)$. Accuracy and precision of visual estimation of each rater, for the different scales proposed, were determined via a linear regression analysis considering the actual damage data as independent variable and the estimated damage data as dependent variable, using InfoStat statistical software (12).

The accuracy of each rater's estimates was determined via the " $t$ " test applied to the intercept of the regression line $a$, to confirm the hypothesis $\mathrm{HO}$ : $\mathrm{a}=0$, and to the slope of the regression line $b$, to confirm the hypothesis $\mathrm{H} 0: \mathrm{b}=1$, at $5 \%$ probability. Values of $a$ different from 0 indicate constant deviations, and $b$ values different from 1 indicate systematic errors in the evaluations. The precision of evaluations was estimated using the $R^{2}$ coefficient of determination and absolute error distribution (estimated damage minus actual damage) $(24,37)$. Reproducibility, which indicates if the scale can be efficiently applied by other raters, was determined using the $R^{2}$ coefficient of determination obtained from the linear regressions between damage values estimated by the different raters combined in pairs $(9,13,28)$.

\section{RESULTS AND DISCUSSION}

The sampled leaflets exhibited between 0 and $96.1 \%$ of leaf area damaged by the two-spotted spider mite; the proposed scales (six-, seven-, eight- and nine-class scales) (table 1, page 257) were developed based on those values. The maximum DLA value recorded is usually found in the field $(7,21)$.

Precision was high for all the scales with $R^{2}$ values ranging between 0.78 and 0.96 (table 2, page 257). A value above 0.75 is considered appropriate for validation in terms of precision $(15,25,26,28)$. In the seven-class scale, the $R^{2}$ value ranged between 0.82 and 0.90 ; this value was higher than 0.80 for all the raters, which confers high precision to leaf damage estimation. Values higher than $80 \%$ are indicated in scales considered of high precision $(9,16,22)$. Accuracy, determined by the proximity between a mean estimate and the actual value, was higher for the seven-class scale, considering both $a$ and $b$ parameters (table 2, page 257). 
The analysis of the value $a$ for the six-, seven-, eight- and nine-class scales showed that $12,10,11$, and 9 raters, respectively, obtained values different from 0 . Regarding the $b$ value, only one of the 13 raters obtained a value significantly different from 1 for the six-, seven-, and eight-class scales. By contrast, for the nine-class scale, seven raters found a value of $b$ significantly different from 1 (table 2).

Values of $a$ obtained by the linear regression between the actual damage and the damage estimated using the seven-class scale varied from -1.01 to 10.39; in turn, 12 of the 13 raters had constant deviations and tendency to overestimate, which agrees with previous works that validated severity scales for leaf diseases $(2,9,14,15,22)$.

Table 1. Upper limit (UL), lower limit (LL) and midpoint (MP) of each class of the six-, seven-, eight- and nine-class scales.

Tabla 1. Límite superior (LS), inferior (LI) y punto medio (PM) de cada clase, para las escalas de seis, siete, ocho y nueve clases.

\begin{tabular}{|c|c|c|c|c|c|c|c|c|c|}
\hline Scale & Class & $\begin{array}{c}\text { Lower } \\
\text { limit } \\
(\%)\end{array}$ & $\begin{array}{l}\text { Midpoint } \\
\text { (\%) }\end{array}$ & $\begin{array}{c}\text { Upper } \\
\text { limit } \\
(\%)\end{array}$ & Scale & Class & $\begin{array}{c}\text { Lower } \\
\text { limit } \\
(\%)\end{array}$ & $\begin{array}{c}\text { Midpoint } \\
\text { (\%) }\end{array}$ & $\begin{array}{c}\text { Upper } \\
\text { limit } \\
(\%)\end{array}$ \\
\hline \multirow{7}{*}{$\begin{array}{l}\text { Six- } \\
\text { Class }\end{array}$} & 1 & 0 & 0 & 0 & \multirow{7}{*}{$\begin{array}{l}\text { Seven- } \\
\text { Class }\end{array}$} & 1 & 0 & 0 & 0 \\
\hline & 2 & 0 & 3.64 & 6.95 & & 2 & 0 & 2.94 & 5.03 \\
\hline & 3 & 6.95 & 13.27 & 25.32 & & 3 & 5.03 & 8.62 & 14.78 \\
\hline & 4 & 25.32 & 48.32 & 72.89 & & 4 & 14.78 & 25.32 & 43.39 \\
\hline & 5 & 72.89 & 85.80 & 92.56 & & 5 & 43.39 & 66.37 & 80.38 \\
\hline & 6 & 92.56 & 96.10 & & & 6 & 80.38 & 88.55 & 93.32 \\
\hline & & & & & & 7 & 93.32 & 96.10 & \\
\hline \multirow{9}{*}{$\begin{array}{l}\text { Eight- } \\
\text { Class }\end{array}$} & 1 & 0 & 0 & 0 & \multirow{9}{*}{$\begin{array}{l}\text { Nine- } \\
\text { Class }\end{array}$} & 1 & 0 & 0 & 0 \\
\hline & 2 & 0 & 2.52 & 3.99 & & 2 & 0 & 2.24 & 3.36 \\
\hline & 3 & 3.99 & 6.34 & 10.06 & & 3 & 3.36 & 5.03 & 7.54 \\
\hline & 4 & 10.06 & 15.96 & 25.32 & & 4 & 7.54 & 11.29 & 16.90 \\
\hline & 5 & 25.32 & 40.17 & 60.78 & & 5 & 16.90 & 25.32 & 37.92 \\
\hline & 6 & 60.78 & 75.28 & 84.42 & & 6 & 37.92 & 55.98 & 70.61 \\
\hline & 7 & 84.42 & 90.18 & 93.81 & & 7 & 70.61 & 80.38 & 86.90 \\
\hline & 8 & 93.81 & 96.10 & & & 8 & 86.90 & 91.25 & 94.16 \\
\hline & & & & & & 9 & 94.16 & 96.10 & \\
\hline
\end{tabular}

Table 2. Intercept $a$, slope $b$ and determination coefficient $R^{2}$ of linear regression between actual and estimated values of damage caused by the two-spotted spider mite to peanut crop, for 13 raters with the use of six-, seven-, eight- and nine-class scales.

Tabla 2. Ordenada al origen $a$, pendiente $b$ y coeficientes de determinación $R^{2}$ de la regresión lineal entre valores de daño real y valores de daño estimado de arañuela roja en el cultivo de maní, para 13 evaluadores con la utilización de las escalas de seis, siete, ocho y nueve clases.

* Indicates that the null hypotheses ( $\mathrm{HO}: \mathrm{a}=0$ $\mathrm{HO}: \mathrm{b}=1$ ) were rejected by the T test: $\mathrm{p} \leq 0.05$.

* Representa situaciones donde la hipótesis nula $\left(\mathrm{H}_{0}: a=0-\mathrm{H}_{0}: \mathrm{b}=1\right)$ fueron rechazadas por el test $\mathrm{T}: \mathrm{p} \leq 0,05$.

\begin{tabular}{|c|c|c|c|c|c|c|c|c|c|c|c|c|}
\hline Class & \multicolumn{3}{|c|}{$\mathbf{6}$} & \multicolumn{3}{|c|}{$\mathbf{7}$} & \multicolumn{3}{c|}{$\mathbf{8}$} & \multicolumn{3}{c|}{$\mathbf{9}$} \\
\hline Rater & $a$ & $b$ & $R^{2}$ & $a$ & $b$ & $R^{2}$ & $a$ & $b$ & $R^{2}$ & $a$ & $b$ & $R^{2}$ \\
\hline $\mathbf{1}$ & $3.17^{*}$ & 1.04 & 0.87 & $3.48^{*}$ & 1.01 & 0.88 & $2.74^{*}$ & 1.01 & 0.90 & $1.90^{*}$ & $1.03^{*}$ & 0.94 \\
\hline $\mathbf{2}$ & $7.45^{*}$ & 0.96 & 0.83 & $8.97^{*}$ & $0.91^{*}$ & 0.83 & $6.55^{*}$ & 0.96 & 0.86 & $8.01^{*}$ & $0.98^{*}$ & 0.90 \\
\hline $\mathbf{3}$ & $3.24^{*}$ & $1.06^{*}$ & 0.87 & $2.74^{*}$ & 1.04 & 0.88 & $2.21^{*}$ & 1.02 & 0.89 & 1.37 & $1.07^{*}$ & 0.93 \\
\hline $\mathbf{4}$ & $9.43^{*}$ & 1.00 & 0.78 & $10.39^{*}$ & 0.98 & 0.82 & $7.77^{*}$ & 1.01 & 0.84 & $9.45^{*}$ & 1.05 & 0.88 \\
\hline $\mathbf{5}$ & $3.62^{*}$ & 1.00 & 0.88 & 0.40 & 0.98 & 0.90 & $1.59^{*}$ & 0.96 & 0.90 & 0.56 & 0.98 & 0.85 \\
\hline $\mathbf{6}$ & $8.02^{*}$ & 0.99 & 0.85 & $4.11^{*}$ & 0.95 & 0.89 & $4.04^{*}$ & $0.94^{*}$ & 0.89 & $2.14^{*}$ & 0.96 & 0.88 \\
\hline $\mathbf{7}$ & $6.67^{*}$ & 1.01 & 0.85 & $3.89^{*}$ & 0.97 & 0.89 & $5.33^{*}$ & 0.95 & 0.88 & $4.07^{*}$ & 1.02 & 0.94 \\
\hline $\mathbf{8}$ & $4.50^{*}$ & 1.05 & 0.87 & 1.15 & 1.03 & 0.89 & $2.26^{*}$ & 1.02 & 0.90 & $1.62^{*}$ & $1.05^{*}$ & 0.94 \\
\hline $\mathbf{9}$ & $7.55^{*}$ & 0.99 & 0.82 & $5.47^{*}$ & 0.95 & 0.82 & $3.00^{*}$ & 0.98 & 0.86 & 0.80 & $1.01^{*}$ & 0.95 \\
\hline $\mathbf{1 0}$ & -0.39 & 1.05 & 0.88 & -1.01 & 1.03 & 0.90 & -1.28 & 1.04 & 0.90 & $-2.06^{*}$ & $1.05^{*}$ & 0.96 \\
\hline $\mathbf{1 1}$ & $2.61^{*}$ & 1.04 & 0.88 & $4.30^{*}$ & 1.02 & 0.88 & $3.50^{*}$ & 1.03 & 0.88 & $3.18^{*}$ & $1.06^{*}$ & 0.95 \\
\hline $\mathbf{1 2}$ & $5.42^{*}$ & 0.99 & 0.84 & $7.26^{*}$ & 0.96 & 0.84 & $4.72^{*}$ & 0.99 & 0.87 & $4.57^{*}$ & 1.01 & 0.94 \\
\hline $\mathbf{1 3}$ & $3.82^{*}$ & 1.03 & 0.86 & $1.75^{*}$ & 1.02 & 0.90 & 1.51 & 1.02 & 0.89 & 0.06 & $1.05^{*}$ & 0.96 \\
\hline
\end{tabular}


In the seven-class scale, the value of $b$ ranged between 0.91 and 1.04 , with a mean of 0.99 , and only one rater showed a tendency to make systematic errors. The narrow range of $b$ and its mean value similar to 1 indicate that the seven-class scale is highly accurate, with similar values to those reported in the validation of other scales $(5,10,13,17,38)$.

According to Sherwood et al. (1983)_and Godoy et al. (2006), leaves with similar severity but different number of lesions generate a tendency to overestimate the disease, mainly when the number of lesions is very high and leaf size is small. This tendency was not observed in the validation of the present scale, despite the damage caused by the two-spotted spider mites (35).

The number of classes of the best validated scale (seven classes) is appropriate, considering that the number should not be too small, since it would have low resolution power, or too high, since it would be difficult to decide on the most appropriate class, as indicated by Campbell and Madden (1990). Overall, most diagrammatic scales range between five and eight classes $(15,37,38,39)$.

Figure 1 shows the seven-class diagrammatic scale generated from the leaflet images, indicating the upper and lower limits and the midpoint values for each class.

Figure 1. Seven-class diagrammatic scale of damage by two-spotted spider mite to peanut elaborated with software images indicating the lower limit, middle point and upper limit for each class.

Figura 1. Escala diagramática de siete clases de daño por arañuela roja en maní confeccionada con las imágenes generadas por el programa, detallando para cada clase el límite inferior, punto medio y límite superior.

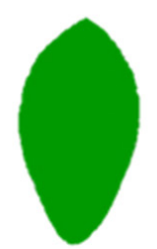

$0 \%$

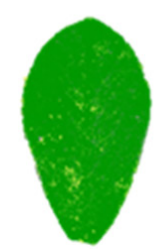

$0 \%-2.94 \%-5.03 \%$

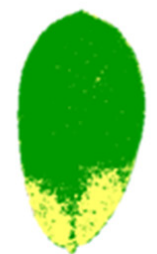

$5.03 \%-8.62 \%-14.78 \%$

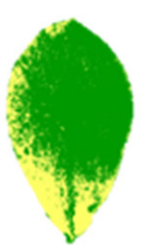

$14.78 \%-25.32 \%-43.39 \%$

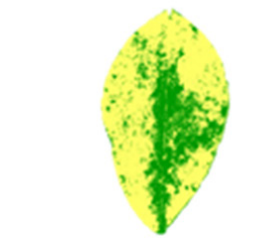

$43.39 \%-66.37 \%-80.38 \%$

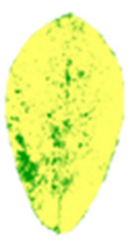

$80.38 \%-88.55 \%-93.32 \%$

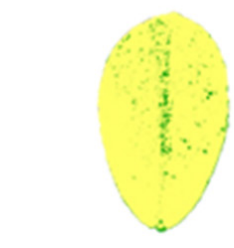

$93.32 \%-96.10 \%$

Absolute errors or residuals, determined as the difference between visually estimated damage and actual damage, for the 13 raters are presented in figure 2 (page 259). Residuals are randomly dispersed around the prediction line, indicating an appropriate fit of the model (8). Most of the absolute errors of the 13 raters were about $10 \%$, a value considered adequate for validation of diagrammatic scales for pests and diseases by several authors (2, $5,9,14,27)$.

The comparison of the estimations of damage among rater pairs, using the seven-class scale, showed $R^{2}$ values ranging between 0.78 and 0.96 (table 3, page 259). Of all the crossed correlations among raters, $100 \%$ yielded $R^{2}$ values higher than $75 \%$, which confirms reproducibility of evaluations using this scale. Similar reproducibility percentages were repeatedly reported with the use of diagrammatic scales $(2,5,9,11,22,26)$. 

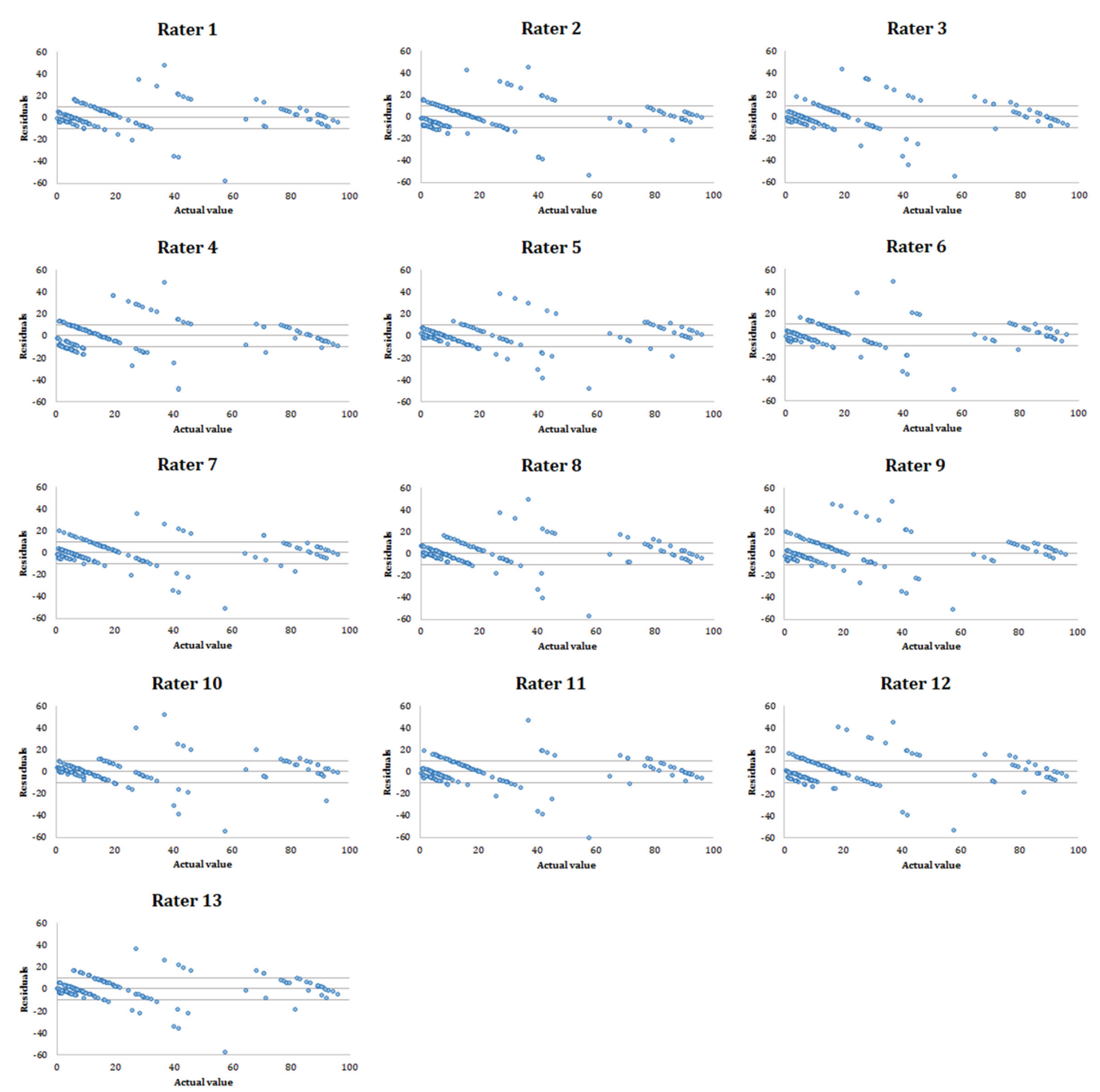

Figure 2. Residues distribution (estimated damage-actual damage) based on actual damage, for the 13 raters, obtained with the use of the seven-class scale of damage by the two-spotted spider mite to peanut.

Figura 2. Distribución de los residuos (daño estimado-daño real) en función del daño real, de los 13 evaluadores, obtenidos con el uso de la escala de siete clases para arañuela roja en maní.

Table 3. $R^{2}$ determination coefficients obtained from linear regression analyses between estimated damage values by 13 raters, combined in pairs.

Tabla 3. Coeficientes de determinación $R^{2}$ obtenidos de los análisis de regresión lineal entre los valores de daño estimados por los 13 evaluadores, combinados de a pares.

\begin{tabular}{|c|r|r|r|r|r|r|r|r|r|r|r|r|}
\hline Rater & $\mathbf{2}$ & $\mathbf{3}$ & $\mathbf{4}$ & $\mathbf{5}$ & $\mathbf{6}$ & $\mathbf{7}$ & $\mathbf{8}$ & $\mathbf{9}$ & $\mathbf{1 0}$ & $\mathbf{1 1}$ & $\mathbf{1 2}$ & $\mathbf{1 3}$ \\
\hline $\mathbf{1}$ & 0.86 & 0.91 & 0.87 & 0.88 & 0.90 & 0.90 & 0.91 & 0.84 & 0.91 & 0.92 & 0.88 & 0.90 \\
\hline $\mathbf{2}$ & & 0.83 & 0.86 & 0.82 & 0.85 & 0.83 & 0.84 & 0.78 & 0.85 & 0.87 & 0.87 & 0.84 \\
\hline $\mathbf{3}$ & & & 0.88 & 0.90 & 0.88 & 0.91 & 0.90 & 0.83 & 0.90 & 0.89 & 0.84 & 0.92 \\
\hline $\mathbf{4}$ & & & & 0.85 & 0.85 & 0.84 & 0.87 & 0.82 & 0.86 & 0.85 & 0.84 & 0.85 \\
\hline $\mathbf{5}$ & & & & & 0.90 & 0.92 & 0.94 & 0.84 & 0.95 & 0.89 & 0.84 & 0.92 \\
\hline $\mathbf{6}$ & & & & & & 0.90 & 0.91 & 0.84 & 0.90 & 0.91 & 0.87 & 0.90 \\
\hline $\mathbf{7}$ & & & & & & & 0.92 & 0.82 & 0.92 & 0.93 & 0.85 & 0.96 \\
\hline $\mathbf{8}$ & & & & & & & & 0.82 & 0.93 & 0.90 & 0.86 & 0.93 \\
\hline $\mathbf{9}$ & & & & & & & & & 0.84 & 0.85 & 0.79 & 0.82 \\
\hline $\mathbf{1 0}$ & & & & & & & & & & 0.92 & 0.87 & 0.93 \\
\hline $\mathbf{1 1}$ & & & & & & & & & & & 0.87 & 0.93 \\
\hline $\mathbf{1 2}$ & & & & & & & & & & & & 0.86 \\
\hline
\end{tabular}




\section{ConCLUSIONS}

According to the validation results, the seven-class diagrammatic scale was the best one in terms of accuracy, precision and reproducibility with values above $0.80,0.75$ and 0.75 respectively.

This is the first scale developed and validated for evaluating damage by the two-spotted spider mite in peanut crop in Argentina. With this scale a loss function will be calculate which will allow the estimation of the EIL of this pest, fundamental parameters for integrated pest management.

\section{REFERENCES}

1. Agüero, D. 2017. 2ª ed. Mercado Nacional e Internacional. In: Fernández, E. M.; Giayetto, O. (Comp.). El cultivo de Maní en Córdoba. Río Cuarto. Córdoba. UNRC Ediciones. 411-435.

2. Barbosa, M. A. G.; Michereff, S. J.; Mora-Aguilera, G. 2006. Elaboracao e validacao de escala diagramática para evalliacao da severidade da ferrugem branca do crisantemo. Summa Phytopatologica. 32(1): 57-62.

3. Berger, R. D. 1980. Measuring disease intensity. In: Teng, P. S.; Krupa, S. V. (Eds.) Crop Loss Assessment. Assessment of Losses which Constrain Production and Crop Improvement in Agriculture and Forestry. Saint Paul MN. University of Minnesota. 28-31.

4. Bock, C. H.; Poole, G. H.; Parker, P. E.; Gottwald, T. R. 2010. Plant disease severity estimated visually, by digital photography and image analysis, and by hyperspectral imaging. Crit. Rev. Plant Sci. 29: 59-107.

5. Boito, G. T.; Crenna, A. C.; Giuggia, J. A.; Giovanini, D.; Oddino, C.; Gerardo, U. A. 2013. Desarrollo y validación de una escala logarítmica diagramática para la evaluación de daño de "orugas defoliadoras" en soja (Glycine max L.) en la región centro-sur de la provincia de Córdoba. Revista de la Facultad de Ciencias Agrarias. Universidad Nacional de Cuyo. Mendoza. Argentina. 45(1): 91-104.

6. Boito, G.; Ornaghi, J.; Giuggia, J. 2017. 2a ed. Artropofauna del cultivo de maní. In: Fernández, E. M.; Giayetto, O. (Comp.). El cultivo de Maní en Córdoba. Río Cuarto. Córdoba. UNRC Ediciones. 355-362.

7. Calza, R., Bulisani, E. A.; Miyasaka, S. 1971. Efeito de alguns acaricidas sobre o acaro rajado (Tetranychus urticae Kock) em feiajo (Phaseolus vulgaris L). Bragantia 30(1): IX-XV.

8. Campbell, C. L.; Madden, L. V. 1990. Monitoring Epidemics: Disease. In: Campell, C. L.; Madden, L. V. (Eds.). Introduction to plant disease epidemiology. New York, Wiley. 108-128.

9. Capucho, A. S.; Zambolim, L.; Duarte, H. S. S.; Parreira, D. F.; Ferreira, P. A.; Lanza, F. E.; Costa, C. R.; Casela, C. R.; Cota, L. V. 2010. Influence of leaf position that correspond to whole plant severity and diagrammatic scale for white spot of corn. Crop Protection 29(9):1015-1020.

10. Crenna, C.; Giovanini, D.; Oddino, C.; Ferrari, S.; Giuggia, J.; Gerardo, U.; Clerici, G.; Bernardini, J. 2018. Desarrollo y validación de escalas para evaluar el daño por trips Caliothrips phaseoli en el cultivo de maní. In: XXXIII Jornada Nacional de maní. 2p.

11. Díaz, C. G., Bassanezi, R. B.; Bergamin Filho, A. 2001. Desenvolvimento e validação de uma escala diagramática para Xanthomonas axonopodis pv. phaseoli em feijoeiro. Summa Phytopathologica, Jaboticabal. 27(1): 35-39.

12. Di Rienzo J. A.; Casanoves F.; Balzarini M. G.; Gonzalez L.; Tablada M.; Robledo C. W. InfoStat versión 2015. Grupo InfoStat, FCA. Universidad Nacional de Córdoba. Argentina. http://www. infostat.com.ar

13. Galvao, A. S.; Gondim, M. G. C.; Michereff, S. J. 2008. Escala diagramática de dano de Aceria guerreronis Keifer (Acari: Eryophidae) en coqueiro. Neotropical Entomology. 37(6): 723-728.

14. Godoy, C. V.; Carneiro, S.; Iamauti, M. T.; Pria, M. D.; Amorim, L.; Berger, R. D.; Bergamin Filho, A. 1997. Diagrammatic scales for bean diseases: development and validation. Journal of Plant Diseases and Protection. 104(4): 336-345.

15. Godoy, C. V.; Koga, L. J.; Canteri, M. C. 2006. Diagrammatic scale for assessment of soybean rust severity. Fitopatol. bras. 31(1): 63-68.

16. Gomes, A. M. A., Michereff, S. J.; Mariano, R. L. R. 2004. Elaboração e validação de escala diagramática para a cercosporiose da alface. Summa Phytopathologica. 30: 38-42.

17. Guimarães Sousa, A. S.; Correa Gondim Jr, M. G.; Sá Argolo, P.; Ramadan Oliveira, A. 2017. Evaluating damage in the perianth: a new diagrammatic scale to estimate population level of Aceria guerreronis Keifer (Acari: Eriophyidae) in coconut fruits. Acta Agronómica. 66(1): 141-147.

18. Jorge, L. A. C.; Silva, D. J. C. B. 2010. SISCOB - Software para análise de cobertura do solo. Ribeirao Preto. Brasil.

19. Kearney, M.; Marinelli, A.; Oddino, C.; March, G. J. 2002. Transmission and dispersal of Sphaceloma arachidis by crop debris and seed from infected peanut. Peanut Science. 29: 13-17. 
20. Kranz, J. 1988. Measuring Plant Disease. In: Experimental Techniques in Plant Disease Epidemiology. J. Kranz, and J. Rotem, J. (Eds.). Berlin. Springer-Verlag, Germany. 35-50.

21. Krips, O. E.; Witul, A.; Willems, P. E. L.; Dicke, M. 1998. Intrinsic rate of population increase of the spider mite Tetranychus urticae on the ornamental crop gerbera: intraspecific variation in host plant and herbivore. Entomologia Experimentalis et Applicata. 89: 159168.

22. Martins, M. C.; Guerzoni, R. A.; Câmara, G. M. S.; Mattiazzi, P.; Lourenço, S. A.; Amorim, L. 2004. Escala diagramática para a quantificação do complexo de doenças foliares de final de ciclo em soja. Fitopatologia Brasileira. Fortaleza. 29(2): 179-184.

23. Massoni, F. A.; Frana, J. E. 2008. Evaluación del daño de trips, mosca blanca y arañuela, sobre el rendimiento del cultivo de soja. Campaña 2008/2009. INTA. Estación Experimental Agropecuaria Rafaela. Información técnica cultivos de verano. Campaña 2010. Publicación miscelánea. 118: 163-174.

24. Michereff, S. J.; Andrade, D. E. G. T.; Noronha, M. A. 2006. Elaboraçao e validaçao de escala diagramática para availaçao da severidades do carvao da folha do caupi. Summa Phytopathologica 32(1): 51-56.

25. Mora Aguilera, G.; Rivas Valencia, P.; Góngora Canul, C.; Tovar Soto, A.; Cristóbal-Alejo, J.; Loeza Kuk, E.; Michereff, S.; Marinelli, A.; Osada-Velázquez, K. 2000. Sistemas computadorizados en la epidemiología: I. 2-LOG ver 1.0 y su aplicación en el diseño de escalas diagramáticas logarítmicas. In: XXIX Simposio Nacional de Parasitología Agrícola. Puerto Vallarta. México. 19p.

26. Noronha, M. A. 2002. Escala diagramática para avaliacao da mancha preta em folhas de citros e efeito da temperatura e da duracao do molhamento na pré-penetracao de conidios de Guignardia citricarpa Kiely (Phyllosticta citricarpa (McAlp) Van der Aa). Thesis MSc. Area de concentracao: Fitopatologia. Piracicaba. Sao Paulo-Brasil. 67p.

27. Nutter, F. W. Jr.; Worawitlikit, O. 1989 Disease. Pro: A computerized disease assessment training program for evaluating and improving a person ability to assess disease proportion. Phytopathology. 79: 11-35.

28. Nutter, F. W. Jr.; Schultz, P. M. 1995. Improving the accuracy and precision of disease assessments: selection of methods and use of computer-aided training programs. Canadian Journal of Plant Pathology. 17: 174-184.

29. Nutter, F. W.; Esker, P. D. 2006. The role of psychophysics in phytopathology: The Weber Fechner law revisited. European J. of Plant Pathology. 114: 199-213.

30. Osada-Velázquez, H. K.; Mora-Aguilera, G. 1997. 2-LOG versión 1.0. Un sistema logarítmico computarizado para la elaboración de escalas y diagramas de intensidad de enfermedad. Texcoco, México. Colegio de Postgraduados. Instituto de Fitosanidad.

31. Plaut, J. L.; Berger, R. D. 1981 Infection rates in three pathosystem epidemics initiated with reduced disease severities Phytopathology. 71: 917-921.

32. Poston, F. L.; Pedigo, L. P.; Welch, S. M. 1983. Economic-injury levels: reality and practicaly. Bull. Entomol. Soc. Am. 29: 49-53.

33. Romero, R. F. 2004. Manejo integrado de plagas. Las bases. Los conceptos. Su mercantilización. Colegio de Postgraduados. Chapingo, Tezcoco. México. 95p.

34. Sherwood, R. T.; Berg, C. C.; Hoover, M. R.; Zeiders, K. E. 1983. Illusions in visual assessment of stagonospora leaf spot of orchardgrass. Phytopathology. 73: 173-177.

35. Smith, J. W. J.; Barfield, C. 1982. Management of preharvest insects. In: Pattee, H. E.; Young, C. T. (Eds.). Peanut Science and Technology. Texas, USA. American Peanut Research and Education Society. 251-325.

36. Souza, I. V.; Gondim Jr., M. G.; Ramos Jr., A. L.; Santos, E. A.; Ferraz, M. I.; Oliveira, A. R. 2012. Population dynamics of Aceria guerreronis (Acari: Eriophyidae) and other mites associated with coconut fruits in Una, state of Bahia, northeastern Brazil. Exp Appl. Acarol. 58(3): 221- 233.

37. Tovar Soto, A.; Hernández Martínez, M.; Cristóbal Alejo, J.; Romero (h), R.; Mora Aguilera, G. 2002. Escala logarítmica diagramática de severidad de la mancha negra (Colletotrrichum gloeosporioides Penz.) en chimoyo (Annona cherimola Mill.). Revista Mexicana de Fitopatología. 20(001): 103-109.

38. Vieira, R. A.; Mesquini, R. M.; Silva, C. N.; Hata, F. T.; Tessmann, D. J.; Scapim, C. A. 2014. A new diagrammatic scale for the assessment of northern corn leaf blight. Crop Protection. 56: 55-57.

39. Zadoks, J. C.; Schein, R. D. 1979. Epidemiology and Plant Disease Management. Oxford University Press. New York. 427p. 